\title{
Determinants and perceptions of social mobility in Poland, 1992-2008
}

\author{
Katarzyna Sokołowska'
}

ABSTRACT

\begin{abstract}
The purpose of this article is to analyse the factors affecting social mobility in Poland, based on results obtained from the estimation of logit models for the years 1992-2008 as well as from interviews asking about the necessary conditions to achieve success in life. Data used in this work come from the Polish General Social Survey carried out by the Institute of Social Studies of the University of Warsaw on a representative sample of adult household members. This set contains interviews conducted in the years 1992-2008 and includes 16,234 respondents. Studies using logit models to answer the question posed in the present study show that the probability of success in life in Poland is determined by both ability and level of education; interview responses to the same question, however, show that family origins, parents' level of education and connections are just as important. Most interestingly, the percentage of people indicating the importance of these factors was higher in 2002 than it was in 1992.
\end{abstract}

KEY WORDS: intergenerational mobility; life success factors; logit model

JEL Classification: C25, J62

${ }^{1}$ Wyższa Szkoła Bankowa w Gdańsku, Poland

\section{Introduction}

The concept of social mobility (Saunders, 2010, p. 1-2; Social mobility, 2008) concerns an individual or social group's ability to change his or her position in the social system. In the case of intragenerational mobility, movement is measured in relation to the life of a single person. If a person's current position is discussed in reference to the position held by his or her parents at the same age, it is described as intergenerational mobility. Profession, income level, education, and other measures of class or socio-economic status can be compared. When a person moves from a lower to a higher social position, he or she achieves social promotion,

Correspondence concerning this article should be addressed to: Katarzyna Sokołowska, Wyższa Szkoła Bankowa w Gdańsku, ul. Dolna Brama 8, 80-821 Gdańsk, POLAND, E-mail: sokkat@wp.pl whereas when a person moves from a higher to a lower position, he or she undergoes social degradation. The factors influencing social mobility are a subject of research in many scientific disciplines, including sociology, psychology, epidemiology, and social medicine. In fact, the social status achieved in adulthood is an important indicator of access to material goods and health status (Adams et al, 2004; Boyle, Norman \& Popham, 2009; Smith et al., 1998). The existence of social mobility also has consequences for social cohesion, equality, economic stability and happiness (Aldridge, 2003). Therefore, it is important to isolate the factors that facilitate mobility as well as those that may pose a barrier to it in order to target material resources that will support the former (Forrest et al., 2011). Most of the research on this subject shows that social, educational, material, cultural and physical factors in individuals' childhoods or early youth impact the direc- 
tion of social mobility in adulthood (Blane, Smith \& Hart, 1999). Depending on the data and methodology used in a particular study, however, this effect is different. In his study of American society, Jencks (1979) showed that the results of youths' mental ability tests are a strong predictor of educational attainment and professional status, even after accounting for variables such as education, occupation and parental income that reduce the strength of this relationship. Similarly, Herrnstein and Murray (1994) found a significant relationship between the results of the AFQT (Armed Forces Qualification Test) and the living conditions of people surveyed in the United States 10 years later. Studies carried out by Korenmana and Winship (2000) on the same sample, however, show that the socioeconomic status of one's parents is equally important as intelligence. Similarly, Breen and Goldthorpe (1999; 2001), who examined English society, found that the social class in which a person originates continues to exert an influence on the social class in which a person will be at the age of 33, even after taking into account the results of the General Ability Test carried out at the age of 11 and effort invested in education. These conclusions mirror similar, earlier findings from Halsey, Heath, and Ridge (1980). Using the same data as Breen and Goldthorpe, however, Saunders (2002) found individuals' class of origin explains about a quarter of the variance in social class at age 33, while individual abilities, motivations and qualifications explain more than $60 \%$ of the variance. A comparable impact on both children's mental abilities and their class of origin was confirmed in studies conducted by Deary and others (2005) in Scotland. On the other hand, Iannelli and Paterson (2005), using data from the 2001 Scottish Household survey, came to the conclusion that the effect of education on attaining a professional position grew for people entering the labour market from 1950-1980, but was on the decline at the time of their study. They also noted that parents' social position determines the social advancement of people with higher education levels to a lesser extent than it does those with lower education. In other words, in the case where children from a higher social class do not achieve the appropriate qualifications, they have family resources (e.g., financial support or social connections) that help them remain in their social class of origin. Studies carried out based on data from Denmark and Canada by
Bingley, Corak and Westergard-Nielsen (2011) showed that most employment opportunities, especially in the case of high salaried positions, were found with help of friends and family.

The literature also encompasses studies examining subjective perceptions of social position (measured by respondents' indications of the places they occupy on a ten-rung social ladder) and the factors that influence this position. If these factors are independent of the respondent's demographics, such as gender, age, or ethnic and racial background, they reflect limited opportunities for social mobility within a given society (Lindemann, 2007). Studies conducted in Western countries show that the probability of identification with a higher social class depends on age, in that it is greater for older people. In these countries, the majority of unemployed and low-income individuals are young (Yamaguchi \& Wang, 2002), whereas gender does not significantly affect people's self-esteem with regard to social position. In the case of Estonia, there are different dependencies where age is also a decisive factor; in this case, however, young people evaluate their position much more highly. This may be due to the social transformation that gave the advantage to social groups that were better able to adapt to new conditions, manage in the market economy and benefit from new technologies (Lindemann, 2007; Pettai, 2002). Discrimination against women in the Estonian labor market causes Estonian women to evaluate their positions lower in comparison to men. Moreover, the key factor influencing the perception of people's positions in society is profession. Some studies, however, indicate that education and achieved income are even more important (Kelley \& Evans, 1995). The influence of education depends on the institutional solutions that exist in a given society. This factor has a strong influence in the Nordic countries and continental Europe, where the level of education has a significant impact on a person's abilities in the labor market (Knudsen, 1988). Much weaker effects are observed in the U.S. and the U.K., where higher education is accessible to many people and therefore does not confer the same level of advantage (Gross, 2003). In Estonia, where education does not guarantee a high income but rather helps people to realise their social ambitions, such as becoming part of the elite (Lindemann, 2007), is not dissimilar. Individuals' status in the labor market 
in Western countries and Estonia have a comparable effect on people's opinions of their social position; i.e., managers assess their position as being high, while unskilled workers put themselves at the bottom of the social hierarchy.

There are very few studies, however, in the area of subjective social mobility, understood as the evaluation of the respondent's professional position compared to the position held by his or her father when the respondent was 14 years old. A lack of studies does not mean that this topic is insignificant. Taking it into account may help to explain different social attitudes and behaviours, such as attitudes to discrimination or life satisfaction (Kelly \& Kelly, 2009). The results obtained on the basis of the ISSP data from 30 countries in $1999(\mathrm{~N}=31,691)$ indicate that five factors have a positive effect on subjective social mobility: level of education, achieved income, being a manager, being male and the respondent's occupational status. Conversely, parents' education and the high position of one's father on The International Socio-Economic Index of Occupational Status (ISEI) have a negative effect (in the latter case, perhaps because children whose parents are already at the top of the social ladder are less likely to move even higher (Kelly \& Kelly, 2009)). Research carried out in Ukraine based on ISSP data from 2009 shows that, as in the work cited above, subjectively perceived social mobility is influenced by factors such as the difference between the economic position of the respondent's profession and the position of his or her father's profession, as well as holding a managerial position. Furthermore, age effects have been indicated (the older the person, the higher their mobility), as well as effects related to one's place of residence (people living in rural areas have a higher subjective mobility) (Oksamytna, 2010).

An analysis of the literature cited above makes it clear that the most frequent topic of study is whether social mobility is affected by factors dependent on the respondent, such as intelligence, ability and educational achievement, or social origins. This was the subject of the author's considerations in a previous article (Sokołowska, 2013), in which the author examined whether Polish society is meritocratic; that is, if all people have the same chance to attain a high social position, which any person can reach if he or she is talented and willing to work hard (Young, 1958).
This study highlights a number of factors, including those testifying to equal opportunities for all in terms of intergenerational mobility, and factors signifying that a given society is far from meritocratic. There was a conclusion that the study results would change if it was possible to account for IQ test results or personal connections in obtaining a job. An examination of these variables was not possible because such questions were not asked in the PGSS; the closest question to this in the survey asks the respondent to assess whether, in his opinion, a given condition for success in life is essential, very important, moderately important, not very important or unimportant. This provides an interesting juxtaposition of how far our judgments about the determinants of success in life are consistent with reality, and whether a particular respondent's situation affects that judgment.

\section{Research methodology and selection of variables}

To examine whether individuals' views on the conditions necessary to achieve success in life coincide with what actually impacts social mobility, the author used the results obtained from the article cited above (Sokołowska, 2013). The data on which the article was based were derived from the Polish General Social Survey (Cichomski, Jerzyński \& Zielinski, 2009a) conducted from 1992-2008. For the period 1992-2002, survey data were obtained from individual interviews with a nationally representative sample of Polish adults; since 2005, data have been obtained from interviews with individuals selected randomly based on their national identification (PESEL) number (Cichomski, Jerzyński \& Zielinski, 2009b). This set includes 16,234 respondents. Tests administered in successive years are independent from one from another. The cited article examined which factors influence the respondent's social position and what determines his or her income and social promotion or degradation. For this purpose, 7 models were estimated. In models 1 through 4 , the dependent variable was the subjective position of the surveyed individual in the social hierarchy, measured using a 10-item, progressive ordinal scale (1 being the lowest, 10 being the highest), and obtained based on answers to the question: in our society, there are groups of people who occupy higher positions and groups who occupy lower positions. Where in the 
Table 1. Sets of explanatory variables available in each period used in the study.

\begin{tabular}{|c|c|c|}
\hline $1992-2008$ & 1999 & 2002 \\
\hline 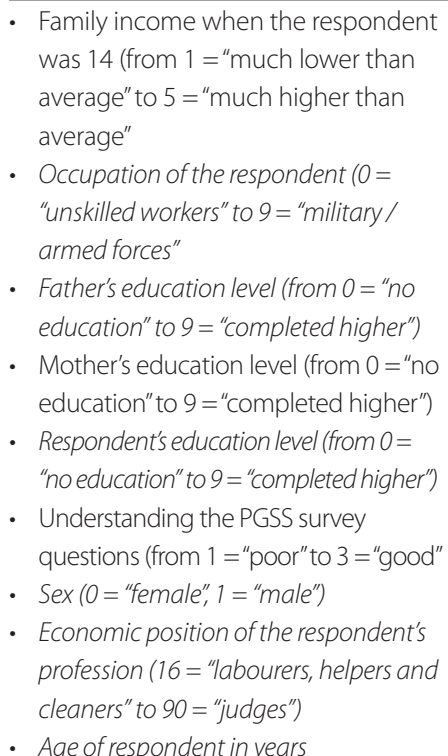 & $\begin{array}{l}\text { - Completion of vocational courses } \\
\text { or further education within the last } \\
\text { three years }(0=\text { "no", } 1=\text { "yes") } \\
\text { - Number of languages known by the } \\
\text { respondent }(0,1,2,3) \\
\text { - Number of books at home when the } \\
\text { respondent was } 14 \text { ( } 1=\text { "none" to } 9= \\
\text { "1000 or more") } \\
\text { - Self-assessment of literacy in Polish and } \\
\text { numeracy }(1=\text { "poor" to } 4=\text { "excellent") } \\
\end{array}$ & $\begin{array}{l}\text { - Degree of respondent's agreement } \\
\text { with the statement,"I am resistant to } \\
\text { sustained failure": from 1,"definitely } \\
\text { not", to 4, "definitely yes" } \\
\text { - Degree of respondent's agreement } \\
\text { with the statement,"I set myself } \\
\text { generally difficult and ambitious } \\
\text { goals": from 1, "definitely not", to 4, } \\
\text { "definitely yes" } \\
\text { - Degree of respondent's agreement } \\
\text { with the statement, "Most of the } \\
\text { things that I care about, I do at least } \\
\text { as well as others": from 1,"I strongly } \\
\text { disagree", to 5,"I strongly agree" } \\
\text { - Degree of respondent's agreement } \\
\text { with the statement, "When I care } \\
\text { about something very much, I usually } \\
\text { cannot get it": from 1,"I strongly } \\
\text { disagree", to 5,"I strongly agree" }\end{array}$ \\
\hline
\end{tabular}

Notes: Variables not shown in italics are only been used in models from (1) to (4)

scale would you place yourself? For models 5 and 6, the dependent variable was subjectively perceived income promotion (1 meaning promotion, 0 meaning no income mobility), while model 7 measured respondents' perceived income degradation (1 meaning degradation, 0 meaning no income mobility). For models 5,6 and 7, the data for the dependent variables were obtained by combining the responses to the question: do you think that, compared with the average Polish family income, your own family income is much lower than average, slightly lower, average, slightly higher or much higher than the average? and the responses to a similar question about the respondent's family income in the period when he was about 14 years old.

The choice of explanatory variables was guided by the literature (Breen \& Goldthorpe, 2001; Deary et al., 2005; Domanski, 2004; Duncan et al., 2002; FirkowskaMankiewicz, 2002; Forrest et al. 2011; Halsey et al., 1980, Saunders, 2010; Waller, 1971) and the availability of the variables in the data set. Among the initial set of variables, variables relating to the father's, mother's and respondent's professions, the respondent's and respon- dent's parents' levels of education, respondent's sex, age in years, and level of family income when the respondent was 14 years old (only for models 1-4), and rated by the interviewer's understanding of the respondent's PGSS survey questions, were found. The final variable was chosen because of the lack of IQ tests results in the data. Moreover, the literature on the subject allows us to assume that the above factor has significant effect on social mobility, which is why the attempts were made to at least partially compensate for the lack of choice available in the survey questions. In addition, depending on the study year, different sets of variables were available, including those related to the knowledge of foreign languages, completed vocational courses, the number of books in the home when the respondent was 14 years old, literacy, numeracy, and features of the respondent's personality. The Table 1 contains a list of variables attached to the models in particular years.

Due to the form of dependent variables, logit models were used to establish dependencies. These models are used when a random component has a logistic distribution and the dependent variable is qualitative. If it is 
an ordinal variable (models 1-4), it is termed a model for sequenced categories, and in the case that there are only two values (as in models 5-7), it is a dichotomous model. The construction and estimation of logit models is described, inter alia, in the works of Cramer (2001; 2003), Greene (2009) and Gruszczyński (2001; 2010).

The logit model for sequenced categories is based on the assumption that the dependent variable $y^{*}$ is a certain unobserved continuous variable, which is a linear function of explanatory variables are stored in the column vector $x_{i}$ and unknown parameters are stored in the column vector $\beta$ :

$y_{i}^{*}=x_{i}^{\prime} \beta+u_{i}$

where $\mathrm{i}=1,2, \ldots, \mathrm{N}$ represents the respondents participating in the survey, $u_{i}$ is a random component with a logistic distribution, and $x_{i}^{\prime}$ is a vector of the explanatory variables stored in the form of the line.

A reflection of the unobservable variable $y^{*}$ is an ordinal variable $y$, which takes, in the case of models from 1 to 4,10 values corresponding to the dependent variable of self-esteem, social position. The relationship between these variables can be expressed as follows:

$y_{i}=j \Leftrightarrow k_{j-1}<y_{i}^{*} \leq k_{j}(j=1,2, \ldots 10)$,

Where the thresholds $k_{j}$ are usually unknown and are estimated together with the parameters $\beta$. Because unobservable variable $y^{*}$ can take on any real value, we can assume that $k_{0}=-\infty, k_{10}=+\infty$ and the number of thresholds requiring estimation is limited to 9 (Gruszczyński, 2010).

The probability $p_{i j}$ that variable $y$ takes the value $\mathrm{j}$ for the i-th person surveyed can be written as:

$p_{i j}=P\left(y_{i}=j\right)=$

$=P\left(k_{j-1}-x_{i}^{\prime} \beta<u_{i} \leq k_{j}-x_{i}^{\prime} \beta\right)=$

$=P\left(u_{i} \leq k_{j}-x_{i}^{\prime} \beta\right)-P\left(u_{i}<k_{j-1}-x_{i}^{\prime} \beta\right)=$

$=F\left(k_{j}-x_{i}^{\prime} \beta\right)-F\left(k_{j-1}-x_{i}^{\prime} \beta\right)$

where $\mathrm{F}$ is the cumulative distribution of the random component $u_{i}$.

In the case of the logistic distribution of the random component, its cumulative distribution is expressed by the formula:

$F(u)=\frac{\exp (u)}{1+\exp (u)}$ and therefore:

$p_{i j}=\frac{\exp \left(k_{j}-x_{i}^{\prime} \beta\right)}{1+\exp \left(k_{i}-x_{i}^{\prime} \beta\right)}-\frac{\exp \left(k_{j-1}-x_{i}^{\prime} \beta\right)}{1+\exp \left(k_{i-1}-x_{i}^{\prime} \beta\right)}$.

The resulting model is called the logit model for ordered categories.

To estimate the parameters of this model, the method of Maximum Likelihood Estimation (MLE) is used, which involves finding the vector of the parameters that guarantees the highest probability of obtaining the observed values in the sample. The use of MLE requires the formulation of a likelihood function and finding its maximum:

$L\left(y \backslash x ; \beta, k_{1}, \ldots, k_{5}\right)=$

$=\prod_{i=1}^{N} \prod_{j=1}^{10}\left[\frac{\exp \left(k_{j}-x_{i}^{\prime} \beta\right)}{1+\exp \left(k_{j}-x_{i}^{\prime} \beta\right)}-\frac{\exp \left(k_{j-1}-x_{i}^{\prime} \beta\right)}{1+\exp \left(k_{j-1}-x_{i}^{\prime} \beta\right)}\right]^{d_{j}}$,

where $d_{i j}$ takes the value of 1 when the i-th person interviewed has chosen $\mathrm{j}$-th category, and the value of 0 if a different category is chosen; this index is calculated from the sample.

In the case of the dichotomous logit model, the subject of explanation is the probability $p_{i}$ of taking by the variable $y$ one of two possibilities ( $y=1$ or $y=0$ ). The probability that variable $y$ takes the value of 1 (which means achieving income promotion for models 5 and 6 and for model 7, income degradation) for the i-th person surveyed can be written as:

$p_{i}=P\left(y_{i}=1\right)=\frac{\exp \left(\beta_{0}+x_{i}^{\prime} \beta\right)}{1+\exp \left(\beta_{0}+x_{i}^{\prime} \beta\right)}$.

The evaluation of models matching was carried out using several ratios (Gruszczyński, 2010).

The first ratio used was McFadden's adjusted pseudo-R2 ratio, expressed by the formula $R_{\alpha F}^{2}=1-\frac{\ln L-p}{\ln L_{0}}$, where $L, L_{0}$ are, respectively, the value of likelihood function of the test model's and the value of likelihood function of the model's considering only the thresholds, and $\mathrm{p}$ is the number of estimated parameters with the exception of thresholds. This measure is less than 1 , it may take negative values. The analysed model displays a good fit to the empirical data if its value is close to 1 . 
The next ratio used was the likelihood ratio test, in which the statistical value is given by the formula $L R=2\left(\ln L-\ln L_{0}\right)$. The statistic has a chi-square distribution with the number of degrees of freedom equal to p. The null hypothesis is rejected if the observed value of the test statistic is higher than the critical value of the test statistic. The lowest level of significance at which the null hypothesis can be rejected is marked as the p-value. This test is used to examine the total significance of all explanatory variables. In this case, the null hypothesis assumes that all model parameters except the thresholds equal zero.

Then, the Akaike Information Criterion $A I C=\frac{-2 \ln L+2 P}{N}$ was used, where $\mathrm{N}$ signifies the sample size and $\mathrm{P}$, the number of estimated model parameters, including thresholds. This criterion does not have a fixed range and can only serve to compare models. The model with the lowest value for this criterion should be chosen.

The final ratio used was the Wald chi-square test, which has the formula $\left(\frac{\hat{\beta}_{m}}{S\left(\hat{\beta}_{m}\right)}\right)^{2}$ and verifies the null hypothesis that the m-th parameter of the model is statistically insignificantly different from zero. The statistic has a chi-square distribution with the number of degrees of freedom equal to 1 . The null hypothesis is rejected if the observed value of the test statistic is higher than the critical value of the test statistic. Tables 2 and 3 show the p-value for the Wald chi-square test.

\section{Results}

Parameter estimates of received models are included in Tables 2 and 3 . In the case of the logit models, the estimated parameter values do not have a direct interpretation as in the linear model; we can only interpret their signs. A positive value of the parameter standing at a given explanatory variable means that its growth has a positive impact on the probability of obtaining a larger value for the dependent variable, assuming that the values of the other explanatory variables do not change. Odds ratios can also be used in the interpretation. The properties of the logit model indicate that they are equal $\exp \left(\hat{\beta}_{m}\right)$ (where $\hat{\beta}_{m}$ is an estimate of the parameter standing at $\mathrm{m}$-th explanatory variable) and show how many times they will change the chances of adoption by the dependent variable higher and not lower category (in the case of dummy variables - the value of 1) in due to unit increase of the explanatory variable ceteris paribus.

Table 2 contains four models. Model 1 was estimated for the years 1992-2008, and a set of explanatory variables was based solely on the respondents' answers to the questions asked in each survey in a given period of time. Model 2 was estimated only for the year 1999 and in addition to the explanatory variables included in model 1 , contains variables concerning knowledge of foreign languages and the completion of vocational courses. as part of the respondents were asked questions on the basis of which these variables were created. Model 3 is different from Model 2, although it also covers responses for 1999; this model was estimated for those respondents who were asked about the number of books at home when they were 14 years old. The division of the respondents into two sub-samples, where alternative additional questions were asked outside the traditional set of indicators, was also dictated by the fact that the extension of the research problems did not increase the execution time for the PGSS (Cichomski et al., 2009b). Model 4, estimated for the year 2002, contains an additional set of variables based on the questions that were asked that year regarding respondents' personality traits. Based on the evaluations of the model parameters in Table 2, it can be concluded that the decisive factor positively impacting the respondent's high self-esteem concerning his or her social position is that respondent's ability to understand the survey questions, followed by his or her level of education. Due to a lack of questions concerning IQ test results, these variables can be regarded as reflecting, to a certain extent, the person's level of intelligence. In addition, in all models, having a profession with a high value on the International Socio-Economic Index of Occupational Status (ISEI) positively affects self-esteem. This scale was developed in 1996 by Ganzeboom and Treiman (1996) and takes values ranging from 16-90, where the highest position is occupied by judges and the lowest by labourers, helpers and cleaners in offices, hotels or other facilities. Moreover, in Model 1, which was estimated for the years 1992 2008, respondent's occupation positively affects social self-esteem. The respondent's age has a low impact and is significant only in the first model. The probability of high self-esteem concerning one's social position decreases with age. These results suggest that young people are more 

Table 3. The estimation results of logistic regression models for the dependent variables of expense promotion and income degradation, measured on a scale from 0 (no mobility income) to 1 (income mobility) (Sokołowska, 2013).

\begin{tabular}{|c|c|c|c|c|c|c|c|c|c|}
\hline \multirow[t]{2}{*}{ Name of the variable } & \multicolumn{3}{|c|}{$\begin{array}{c}5) \\
1992-2008 \\
\text { - dependent variable } \\
\text { promotion }\end{array}$} & \multicolumn{3}{|c|}{$\begin{array}{c}\text { (6) } \\
1999 \\
\text { - dependent variable } \\
\text { promotion }\end{array}$} & \multicolumn{3}{|c|}{$\begin{array}{c}\text { (7) } \\
\text { 1992-2008 } \\
\text { - dependent variable } \\
\text { degradation }\end{array}$} \\
\hline & $\hat{\beta}_{m}$ & $\exp \left(\hat{\beta}_{m}\right)$ & p-value & $\hat{\beta}_{m}$ & $\exp \left(\hat{\beta}_{m}\right)$ & p-value & $\hat{\beta}_{m}$ & $\exp \left(\hat{\beta}_{m}\right)$ & $\mathrm{p}$-value \\
\hline const & -3.98 & 0.02 & .0000 & -1.31 & 0.27 & .5413 & 1.03 & 2.79 & .1025 \\
\hline Father's education level & 0.08 & 1.08 & .0300 & 0.15 & 1.16 & .2861 & -0.04 & 0.96 & .2162 \\
\hline Respondent's education level & 0.25 & 1.28 & .0000 & 0.07 & 1.07 & .6303 & -0.23 & 0.79 & .0000 \\
\hline Economic position of resp's profession & 0.02 & 1.02 & .0182 & 0.01 & 1.01 & .7402 & -0.01 & 0.99 & .4459 \\
\hline Sex (male) & 0.22 & 1.24 & .0003 & 0.21 & 1.23 & .3664 & -0.15 & 0.86 & .0410 \\
\hline Age of the respondent & 0.01 & 1.01 & .0794 & 0.00 & 1.00 & .8370 & 0.01 & 1.01 & .0026 \\
\hline Occupation of the respondent & 0.02 & 1.02 & .7134 & -0.05 & 0.95 & .7371 & -0.13 & 0.88 & .0166 \\
\hline $\begin{array}{l}\text { Number of languages known by the } \\
\text { respondent }\end{array}$ & - & - & - & 0.70 & 2.02 & .0343 & - & - & - \\
\hline Self-assessment of numeracy & - & - & - & 0.83 & 2.29 & .0286 & - & - & - \\
\hline $\begin{array}{l}\text { Self-assessment of literacy and } \\
\text { writing skills }\end{array}$ & - & - & - & 0,43 & 1.54 & .3414 & - & - & - \\
\hline Adjusted McFadden Pseudo-R2 & .120225 & & & .16993 & & & .15492 & & \\
\hline$L R$ & 273.40929 & & & 31.78082 & & & 219.63106 & & \\
\hline$p$-value & .00000 & & & .00010 & & & .00000 & & \\
\hline AIC & .719261 & & & .73397 & & & 1.10015 & & \\
\hline $\mathrm{N}$ & 2778 & & & 220 & & & 1090 & & \\
\hline
\end{tabular}

Notes: For the year 1999, an additional model with the dependent variable of income promotion was estimated, because that year, questions about foreign language skills, literacy and numeracy were included on the PGSS. For the year 2002 there were neither estimates nor an additional model for the dependent variable of income promotion or degradation (also there was no separate model for this variable for the year 1999) due to the lack of significance of the parameter estimates for attached variables in those years. Estimates of parameters significantly different from zero at a significance level $\leq 10 \%$ are shown in bold.

optimistic when they assess their social position, and perhaps also that young Poles are more successful in life than their older counterparts. This may be due to the period of transition, which, as in Estonia (Lindemann, 2007; Pettai, 2002), provided young people with the opportunity to make a career. The positive symbol of the parameter for the gender variable means that in Polish society, men are more likely to occupy a high social position than women, which demonstrates the disadvantaged situation of Polish women. Another factor that positively influences the probability of high social self-esteem, found in Model 2 (estimated for 1999), is the number of foreign languages spoken by the respondent, as well as the respondent's completion of professional courses within the last 3 years. In Model 4, measuring the year 2002,character traits such as resistance to failure, setting difficult or ambitious goals, having high self-esteem manifested in respondent's agreement with the statement: "Most of the things that I care about, I do at least as well as others" and persistence in the pursuit of the goals (negative sign for the answer to the question: "When I really want something, I usually cannot get it") positively affects social self-esteem. In most cases, the above-mentioned factors speak to the fact that Polish society is rooted in a meritocracy. The significance of the parameters in Model 1 for variables such as family income when the respondent was 14 years old, parental education level, and in model 3, the number of books at home when the respondent was 14 years old, attest to the fact that social position is partly determined by background. This means that children with more affluent and educated parents will find it easier to achieve a higher social position; however, the parameters of these variables 


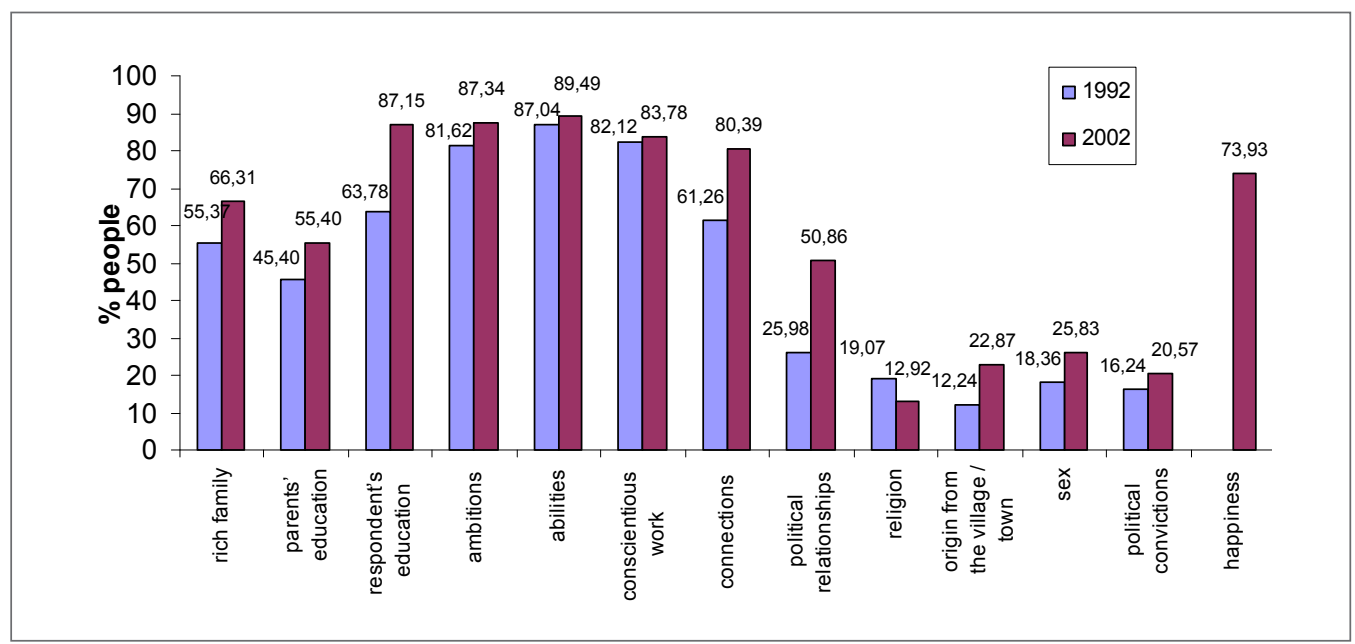

Figure 1. The percentage of people indicating a particular factor as crucial or very important to succeed in life, based on answers given by respondents in 1992 and 2002

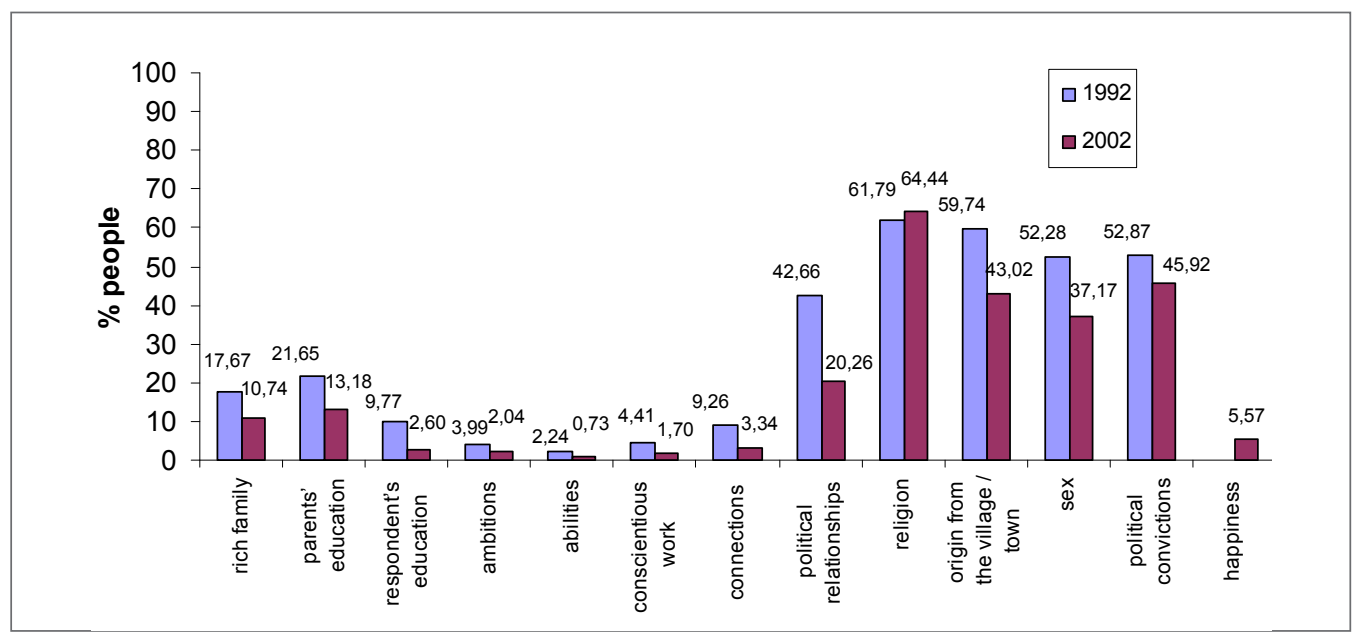

Figure 2. The percentage of people indicating a particular factor as not very important or irrelevant to succeed in life, based on the answers given by respondents in 1992 and 2002

are statistically insignificant among the variables studied, such as the nature of the respondent's qualities (Model 4), the number of foreign languages they know or vocational courses they have successfully completed (Model 2). Comparing the obtained results to the literature cited above, it can be seen that in the factors influencing social self-esteem, Polish society is similar to Estonian society, with the exception that in Polish society, education levels have a stronger influence than professional position. Estonia displays an inverse relationship (Lindemann, 2007).

As for the probability of promotion (Model 5 in Table 3 ), the most influential of the variables studied are education, gender (being male increases the probability of success), the economic position of the respondent's profession, father's level of education and the respondent's age $(\mathrm{p}=.0794$; the probability increases with age). For 
1999 (Model 6), only the number of foreign languages known and the respondent's self-assessment of numeracy showed positive effects. The probability of income degradation (model 7) is increased by a low level of education, pursuing an unskilled occupation, being a woman and being older. Once again, education level was a factor for which the parameter value was relatively high, which may indicate that it is a major determinant in deciding the place we will hold on the social ladder. Unfortunately, gender followed soon after, in which case the sign of the parameter confirmed the poor situation of women in Poland in terms of opportunities for income promotion. This research has helped to confirm results from previous studies that note the positive impact of education and the economic position of the respondent's profession on subjective social mobility; these findings did not confirm the negative effect of the father's education level, however, while the effect of age proved to be controversial.

For almost all logit models presented in this study, the LR likelihood ratio test allows for the rejection of the null hypothesis of a total insignificance of all variables at $p=0.0000$ (with the exception of Model 6, for which $\mathrm{p}=0.00010$ ). The values of the McFadden's adjusted pseudo-R2 ratio for the obtained models range from 0.03363 to 0.16993 ; the value of this factor is generally lower for models estimated using cross-sectional data than for models estimated on the basis of time series (Gruszczyński, 2010, p. 62).

At this point, the author will examine whether the results obtained in the article discussed above (Sokołowska, 2013) coincide with Poles' views on the conditions necessary to achieve success in life. Respondents were asked to rate the factors that may affect the achievement of success on a 5-point scale from 1 , negligible, to 5, crucial. Figure 1 shows the percentage of people who indicated that any given category was crucial or very important. The data were collected first in 1992 and then in 2002. Figure 2 shows the percentage of people who rated a given category as not very important or irrelevant. Respondents who chose the middle answer indicating that a category of was average importance have been omitted from the analysis.

These results show that the majority of Poles feel that the decisive qualities for achieving success in life are ability, ambition and conscientious work. There has also been a noticeable increase in the number of people who believe that education is very important. Less fortunate is the result that the percentage of people who feel that coming from a rich family, parents' education levels and connections have a very important impact on success has increased, the latter by as much as 19.13 percentage points. The number of people choosing this factor as important in 2002 is comparable to the number of people for whom factors indicating that Polish society could be meritocratic were important. Testifying to the unfavourable public situation, the number of people who believe that success in life can be determined by political connections has increased dramatically (from $25.98 \%$ to $50.86 \%$ ), as has the percentage of people who feel similarly about political convictions (from 16.24\% to $20.57 \%$ ), although in this case, more people think political convictions are not significant than the reverse. The number of people who believe that gender influences success has also increased, but this factor appears to be less decisive than studies that use logit models have suggested. Similarly, a greater percentage of people (22.87\%, compared with $12.24 \%$ for the year 1992) in 2002 declared that being born in a village or town is significant for later success, which may indicate that people from these areas have less opportunities for social promotion. Also interesting is the fact that in 2002 (in 1992 the question was not asked), as much as $73.93 \%$ of people said that happiness is important to achieve success in life and that happiness was almost as important as the other factors mentioned above.

The author next decided to explore whether one's views on success are influenced by experiencing a promotion or degradation of income. Therefore, figure 3 shows the percentage of people who identified a particular factor as being very important or having decisive importance, divided between those who achieved income promotion and those who experienced income degradation. Data are from the years 1992 to 2002 (in 2005 and 2008, the question on the conditions for achieving success in life was not asked). Figure 4 shows the percentage of people who considered that a factor was not very important or unimportant. The biggest differences in responses in the case of figure 3 (of approximately 10 percentage points) are for factors such as being born into a rich family, connections and happiness, which may indicate that individuals who failed in life perceive Polish society as less meritocratic than people who achieved success.

Figures 2 and 4 show that in all considered cases, the highest percentage of indications that a given fac- 


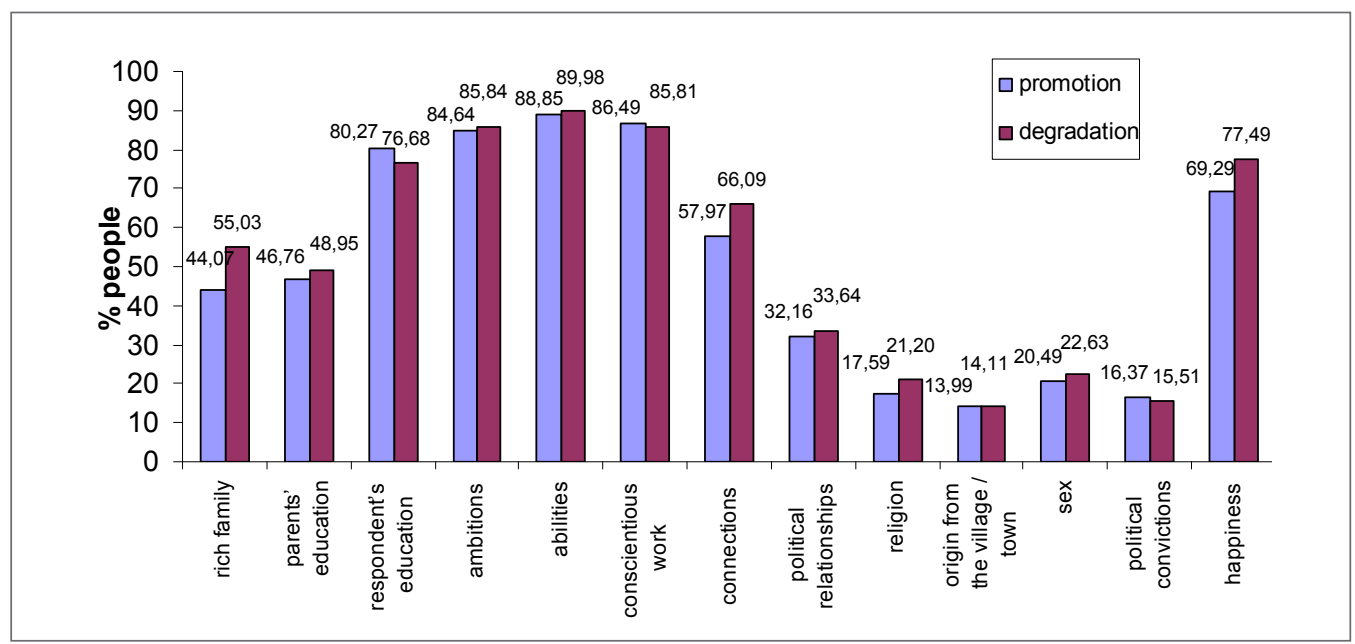

Figure 3. The percentage of people who experienced income promotion versus income degradation who indicated a particular factor as crucial or very important to succeed in life, based on answers given by respondents in 1992-2002

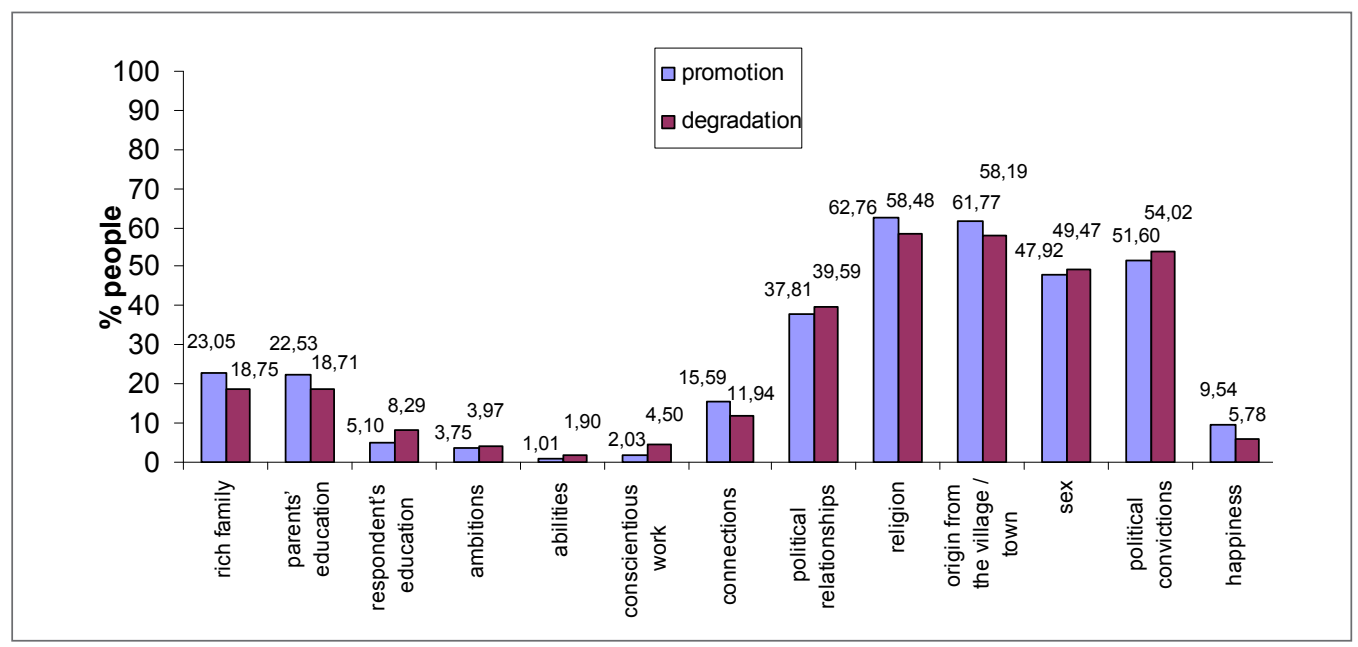

Figure 4. The percentage of people who experienced income promotion versus income degradation who indicated a particular factor as not very important or insignificant to succeed in life, based on answers given by respondents in 1992 and 2002

tor was not very important or completely unimportant in achieving success in life have factors: religion, being from a village or town, political convictions and gender.

The answers of individuals with above average incomes compared to answers those with belowaverage incomes led to similar conclusions, and those statements will therefore not be presented in the article.

\section{Conclusion}

In conclusion, it is clear that our success in life is decided not only by our abilities, education and work habits but also by the family to which we were born, our gender and our age. These conclusions can be drawn either on the basis of the models used in the study, or on the analysis of respondents' answers. What we consider to be the possibility or likelihood of social mobility in Polish 
society does not diverge from reality. In addition, data obtained from answers to the question about the conditions for achieving success shows that connections or political affiliations are also important. These factors were not taken into account in the logit models due to the lack of questions about these factors in the PGSS. Identifying these factors as important is a worrisome phenomenon, proving that Polish society may yet be far from providing equal opportunities for all. The increasing importance of having a rich family for success in life may also indicate that Polish society is not going well. Being from a poor family may, for example, be an inhibiting factor to obtaining a good education. Education is theoretically free in Poland, but parents must be able to afford to house, clothe and feed their school-age children. It is also possible payable learning in extramural system but then it is necessary to have a job that allows getting by and paying tuition. The studies using logit models show that the possibilities for success in life in Poland are determined in the first place by ability and education. However, the importance of factors such as a rich family, parental education levels and connections attest to the fact that origins are similarly important in determining our life chances.

\section{References}

Adams, J., White, M., Pearce, M. S., \& Parker, L. (2004). Life course measures of socioeconomic position and self reported health at age 50: prospective cohort study. Journal Of Epidemiology And Community Health, 58 (12), 1028-1029.

Aldridge, S. (2003). The facts about social mobility. New Economy, 10 (4), 189-193.

Bingley, P., Corak, M. \& Westergård-Nielsen, N. (2011). The Intergenerational Transmission of Employers in Canada and Denmark. IZA DP No. 5593

Blane, D., Smith, G. D., \& Hart, C. (1999). Some social and physical correlates of intergenerational social mobility: Evidence from the West of Scotland Collaborative Study. Sociology, 33 (1), 169-183.

Boyle, P. J., Norman, P., \& Popham, F. (2009). Social mobility: Evidence that it can widen health inequalities. Social Science \& Medicine, 68 (10), 1835-1842.

Breen, R., \& Goldthorpe, J. H. (1999). Class inequality and meritocracy: a critique of Saunders and an alternative analysis. British Journal of Sociology, 50 (1), 1-27.

Breen, R., \& Goldthorpe, J. H. (2001). Class, mobility and merit: the experience of two British birth co- horts. European Sociological Review, 17 (2), 81-101. Cichomski, B., Jerzyński, T., \& Zieliński, M. (2009a). Polskie Generalne Sondaże Społeczne: struktura skumulowanych wyników badań 1992-2008 [Polish General Social Surveys: Cumulative computer data set from 1992 to 2008]. Warsaw: Institute for Social Studies, Warsaw University. Available at http://www.ads.org. pl/pobieranie-zbioru-danych.php?id=53

Cichomski, B., Jerzyński, T., \& Zieliński, M. (2009b). Polskie Generalne Sondaże Społeczne: skumulowany komputerowy zbiór danych 1992-2008 [Polish General Social Surveys: the structure of the cumulative results of studies from 1992 to 2008]. Warsaw: Institute for Social Studies, Warsaw University. Available at http://www.ads.org.pl/pobieranie-zbioru-danych.php?id=53

Cramer, J. S. (2001). An introduction to the logit model for economists ( $2^{\text {nd }}$ ed.). London, UK: Timberlake Consultants Ltd.

Cramer, J. S. (2003). Logit models from economics and other fields. Cambridge, UK: Cambridge University Press.

Deary, I. J., Taylor, M. D., Hart, C. L., Wilson, V., Smith, G. D., Blane D., \& Starr , J. M. (2005). Intergenerational social mobility and mid-life status attainment: influences of childhood intelligence, childhood social factors, and education. Intelligence 33 (5), 455-472.

Domański, H. (2004). O ruchliwości społecznej w Polsce [The social mobility in Poland]. Warsaw: Institute of Philosophy and Sociology PAN.

Duncan, G., Kalil, A., Mayer, S. E., Tepper, R. P., \& Monique, R. (2002). The Apple Does not Fall Far from the Tree (Working Paper No. 02-17). Institute for Policy Research.

Social mobility (2008). In Encyklopedia PWN. Warsaw: PWN.

Kelley, J. \& Evans, M. D. R. (1995). Class and class conflict in six western nations. American Sociological Review, 60 (4), 157-178.

Firkowska-Mankiewicz, A. (2002). Intelligence and success in life. Warsaw, Poland: IfiS.

Forrest, L. F., Hodgson, S., Parker, L., \& Pearce, M. S. (2011). The influence of childhood IQ and education on social mobility in the Newcastle Thousand Families birth cohort. BMC Public Health, 11 (1), 895.

Ganzeboom, H. B. G., \& Treiman, D. J. (1996). Internationally comparable measures of occupational 
status for the 1988 international standard classification of occupations. Social Science Research, 25 (3), 201-239.

Greene, W. H., \& Hensher, D. A. (2009). Modeling Ordered Choices. Available from http://pages.stern. nyu.edu/ wgreene.

Groß, M. (2003). Educational systems and perceived social inequality: the institutional base of class formation. European Societies 2 (5), 193-225.

Gruszczyński, M. (Ed.). (2010). Mikroekonometria. Modele i metody analizy danych indywidualnych [Micro econometrics. Models and methods of analysis of individual data]. Warsaw: Oficyna a Wolters Kluwer business.

Gruszczyński, M. (2001). Modele i prognozy zmiennych jakościowych $w$ finansach $i$ bankowości [The models and forecasts of qualitative variables in finance and banking]. Warsaw: Warsaw School of Economics.

Halsey, A., Heath, A., \& Ridge, J. (1980). Origins and destinations: Family, class and education in modern Britain. Oxford, UK: Clarendon Press.

Herrnstein, R. J., \& Murray, C. (1994). The bell curve. Intelligence and Class Structure in American Life. New York, NY: Free Press.

Iannelli,, C. \& Paterson, L. (2005). Does Education Promote Social Mobility? (CES Briefing No. 35). Centre for Educational Sociology, University of Edinburgh.

Jencks, C. (1979). Who gets ahead?: The determinants of economic success in America. New York, NY: Basic Books.

Kelly, S. M. C. \& Kelly, C. G. E. (2009). Subjective social mobility: data from thirty nations. In M. Haller, R. Jowell, T. W. Smith (Eds.), The International Social Survey Programme, 1984-2009: charting the globe (pp. 106-124). London, UK: Routledge.

Knudsen, K. (1988). Class identification in Norway: explanatory factors and life-cycle differences. Acta Sociologica, 31 (1), 69-79.

Korenman, S. \& Winship, C. (2000). A Re-analysis of The bell curve: Intelligence, family background, and schooling. In: K. Arrow, S. Bowles, \& S. Durlauf (Eds.), Meritocracy and economic inequality (pp. 137-178). Princeton, NJ: Princeton University Press.

Lindemann, K. (2007). The impact of objective characteristics on subjective social position. TRAMES, 11(61/56), 54-68.
Oksamytna, S. (Ed.). (2010). Суб'єктивне сприйняття соиіальної мобільності: досвід міжнародного дослідження та тендениії в Үкраїні [Subjective perception of social mobility: international research experience and trends in Ukraine]. Наукові записки Національного університету “Києво-Могилянська академія". (Том 109). Київ: Могилянська академія [Scientific Proceedings of the National University of "Kyiev-Mohyla Academy". (Vol. 109). Kiev: Mohyla Academy].

Pettai, I. (2002). Kihistumine kui problem [Stratification as a Problem]. In R. Vetik (Ed.), Kaks Eestit [Two Estonias]. (pp.118-126). TPÜ kirjastus: Tallinn.

Saunders, P. (2002). Reflections on the meritocracy debate in Britain: a response to Richard Breen and John Goldthorpe. British Journal of Sociology, 53 (4), 559-574.

Saunders, P. (2010). Social Mobility Myths. London, UK: Civitas: Institute for the Study of Civil Society. Smith, G. D., Hart, C., Watt, G., Hole, D., \& Hawthorne, V. (1998). Individual social class, area-based deprivation, cardiovascular disease risk factors and mortality: The Renfrew and Paisley study. Journal of Epidemiology and Community Health, 52 (6), 399-405.

Sokołowska, K. (2013). Analiza czynników wpływających na mobilność społeczną w Polsce w latach 1992-2008 $\mathrm{z}$ wykorzystaniem modeli logitowych. [Analysis of factors affecting social mobility in Poland in 19922008 that use logit models.]. Zeszyty Naukowe Wyższej Szkoły Bankowej we Wrocławiu, 2 (34), 361-378.

Waller, J. H. (1971). Achievement and social mobility: Relationships among IQ score, education, and occupation in two generations. Biodemography and Social Biology, 18 (3), 252-259.

Yamaguchi, K. \& Wang Y. (2002). Class identification of married employed women and men in America. American Journal of Sociology, 108 (2), 440-475.

Young, M. (1958). The Rise of the Meritocracy 18702033: An Essay on Education and Equality. London, UK: Thames and Hudson. 
